\title{
SITOTOKSISITAS INVERTEBRATALAUT SEBAGAI BIOMARKER LINGKUNGAN DI KAWASAN KONSERVASI PERAIRAN PULAU BANDA
}

\section{Cytotoxicity of Marine Invertebrate as an Environmental Biomarker in the Marine Protected Area of Banda Island}

\author{
Asri Pratitis $^{1 *}$, Rini Susilowati ${ }^{1}$ dan Hedi Indra Januar ${ }^{1,2}$ \\ ${ }^{1}$ Pusat Penelitian dan Pengembangan Daya Saing Produk dan Bioteknologi Kelautan dan Perikanan, \\ JI. KS Tubun Petamburan VI Slipi Jakarta Pusat Indonesia \\ 2Jurusan IImu Kelautan, Sekolah Pascasarjana Institut Pertanian Bogor, \\ Jl. Raya Dramaga, Kampus IPB, Bogor, Indonesia \\ * Korespondensi Penulis: asripra@gmail.com \\ Diterima: 28 Juni 2016; Disetujui: 30 Oktober 2016
}

\begin{abstract}
ABSTRAK
Penelitian di bidang ekologi menunjukkan bahwa wilayah terumbu karang yang terjaga dengan baik oleh konservasi menjadi tempat yang ideal bagi biota invertebrata untuk menghasilkan senyawa bioaktif farmakologis. Penelitian ini bertujuan memperoleh informasi mengenai sitotoksisitas dari spons, karang lunak dan ascidian yang berasal dari perairan Pulau Banda. Informasi sitotoksisitas invertebrata laut tersebut selanjutnya digunakan sebagai acuan dalam mempelajari sistem konservasi yang telah dilakukan. Lima jenis invertebrata laut (Sarcophyton sp., Nephthea sp., Hyrtios sp., Stylissa sp., dan Polycarpa sp.) diambil (lima ulangan acak) di kawasan konservasi Pantai Wali, Desa Solomon, Pulau Banda. Penapisan sitotoksisitas dilakukan terhadap ekstrak etanol dari keseluruhan sampel. Hasil penapisan memperlihatkan bahwa Stylissa sp. merupakan biota yang paling potensial karena ekstrak etanol dari Stylissa sp. memiliki daya sitotoksisitas tertinggi dibandingkan jenis invertebrata yang diujikan lainnya. Namun demikian, sitotoksisitas biota-biota yang diperoleh dari perairan ini tergolong rendah. Perbandingan multidimensional scaling (MDS) nilai sitotoksisitas antara sampel invertebrata dari perairan Banda dan perairan lainnya menunjukkan bahwa karakteristik perairan Pulau Banda berada pada level baik dan rendah. Oleh karena itu, sistem konservasi harus dioptimasi lebih lanjut agar dapat menjaga keberlangsungan plasma nutfah di perairan Pulau Banda.
\end{abstract}

KATAKUNCI : ascidian, karang lunak, spons, perairan Pulau Banda, sitotoksisitas

\begin{abstract}
Research in the field of ecology showed that the well-preserved coral reef in conservation regions is an ideal place for invertebrates to produce their active compounds. This study aims to obtain the information about the cytotoxicity of sponges, soft corals and ascidians that were collected from Banda Island water. The cytotoxicity information of those marine invertebrates were used as a benchmark in studying the conservation system that have been applied in Banda Island water. Five species of marine invertebrates (Sarcophyton sp., Nephthea sp., Hyrtios sp., Stylissa sp., and Polycarpa sp.) were collected (five replicates) from conservation area at Wali Beach, Solomon Village, Banda Island. The cytotoxic screening was conducted on ethanol extract of overall samples. The results showed that Stylissa $s p$. is the most potential organism since the ethanol extract of Stylissa sp. had the highest cytotoxic activity among the other samples. However, the overall cytotoxicity value of organism that was collected from Banda Island water is low. Multidimensional scaling (MDS) comparison of the cytotoxicity value among invertebrates from Banda Island water and other marine conservation revealed that environmental condition of Banda Island water was in good and low level. Therefore, the conservation system should be optimized in order to keep the sustainability of the genetic resources in Banda Island water.
\end{abstract}

KEYWORDS: ascidian, soft coral, sponge, Banda Island water, cytotoxicity 


\section{PENDAHULUAN}

Invertebrata terumbu karang merupakan obyek eksplorasi bahan alam laut bioaktif yang potensial. Golongan biota ini, seperti spons dan karang lunak, mampu menghasilkan metabolit bioaktif dengan diversitas tinggi (Bhakuni \& Rawat, 2005; Faulkner, 2001). Analisis bibliografik memperlihatkan adanya penambahan 7415 senyawa baru dari biota invetebrata spons dan karang lunak dalam database Marine Natural Products pada kurun waktu 1990-2009 (Leal, Puga, Serôdio, Gomes \& Calado, 2012). Biota invertebrata menjadi sumber utama dari penemuanpenemuan struktur senyawa bioaktif baru dari wilayah perairan. Beberapa bahan obat yang merupakan turunan dari struktur senyawa bahan alam laut telah diproduksi secara komersial, misalnya Prialt ${ }^{\circledR}$, Yondelis $\AA$, dan Carragelose ${ }^{\circledR}$ (Harvey, 2008; Kiuru et al., 2014). Namun selain itu, terdapat juga sejumlah besar kandidat struktur potensial dari bahan alam laut yang gagal pada pengujian selektivitas target maupun klinis. Hal ini yang menjadikan eksplorasi bahan alam laut dilakukan secara berkesinambungan untuk mendapatkan model "lead compound" baru pada target bioaktivitas farmakologi tertentu (Januar, 2016a).

Senyawa bioaktif dihasilkan oleh invertebrata sebagai reaksi ekologisnya terhadap lingkungan. Senyawa tersebut, yang umumnya bersifat toksik, dipergunakan oleh biota dasar laut di area terumbu karang untuk pertahanan dari predator, mikroorganisme patogen, maupun persaingan untuk mendapatkan ruang hidup di wilayah dasar terumbu karang (Ebada, Lin \& Proksch, 2010; Haber, Carbone, Mollo, Gavagnin \& Ilan, 2011; Hoeksema \& De Voogd, 2012; Kelly, Jensen, Henkel, Fenical \& Pawlik, 2003; Pawlik, 2011). Oleh karena itu, lingkungan terumbu karang yang baik akan memiliki berbagai interaksi persaingan ruang hidup dari berbagai biota laut. Hal ini menjadi pemicu biota invertebrata untuk menghasilkan berbagai senyawa bioaktif dengan tingkat potensi tinggi (DeCaralt et al., 2013). Penelitian di bidang ekologi laut telah menemukan adanya hubungan antara kuantitas senyawa bioaktif spons dan karang lunak dengan tingkat kualitas lingkungan (Januar, Hendrarto, Chasanah \& Wright, 2011; Januar, Marraskuranto, Patantis \& Chasanah, 2012; Januar, Pratitis \& Bramandito, 2015a). Berdasarkan hal ini, maka wilayah konservasi terumbu karang menjadi lokasi penelitian kimia bahan alam yang tepat. Pada lingkungan terumbu karang dengan kualitas perairan yang baik, akan ditemukan biota invertebrata yang menghasilkan senyawa bioaktif dalam jumlah yang tinggi. Senyawa aktif tersebut pada umumnya bersifat sitotoksik (Januar et al., 2015b). Selain itu, dengan adanya korelasi antara biopotensi dan kualitas lingkungan, maka data biopotensi wilayah perairan tertentu juga dapat dijadikan sebagai acuan dalam pelaksanaan sistem konservasi wilayah perairan tersebut.

Kawasan konservasi perairan Pulau Banda memiliki karakter yang berbeda dengan wilayah perairan Indonesia lainnya. Wilayah ini memiliki gunung api dan retakan $\mathrm{CO}_{2}$ hidrotermal, yang menjadikan kondisi lingkungan unik bagi interaksi ekologis invertebrata laut (Januar, Zamani, Soedharma \& Chasanah, 2016b). Inisiasi konservasi perairan di wilayah kepulauan Banda telah dilakukan sejak tahun 2009 oleh berbagai pihak. Pada tahun 2014, penerapan sistem zonasi di wilayah ini mulai diterapkan berdasarkan Peraturan Menteri Kelautan dan Perikanan No. 58 tahun 2014 tentang Rencana Pengelolaan Zonasi Taman Wisata Perairan Laut Banda di Provinsi Maluku. Karakter perairan yang unik dan penerapan zonasi yang tergolong baru merupakan faktor yang mendasari penelitian ini. Penelitian dilakukan untuk mengeksplorasi potensi bioaktif dari biota invertebrata laut asal perairan Pulau Banda. Informasi tersebut selanjutnya dapat digunakan sebagai salah satu acuan dalam penerapan sistem konservasi di perairan Pulau Banda.

\section{BAHAN DAN METODE}

\section{Pengambilan dan Preservasi Sampel}

Pengambilan sampel dilakukan dengan teknik penyelaman Self-Contained Underwater Breathing Apparatus (SCUBA) di perairan Pantai Wali, Desa Solomon, Pulau Banda (4 3' 26,442" Lintang Selatan dan $129^{\circ} 56^{\prime} 34,739^{\prime \prime}$ Bujur Timur). Perairan ini termasuk di dalam kawasan konservasi Taman Wisata Perairan Laut Banda, Provinsi Maluku. Lima jenis biota invertebrata yang secara visual memiliki tutupan tinggi diambil sebanyak $20 \mathrm{~g}$ dengan 5 ulangan acak. Identifikasi yang dilakukan berdasarkan Hooper (2003) dan Fabricius (2008) menemukan bahwa kelima jenis sampel adalah Sarcophytonsp., Nephthea sp., Hyrtios sp., Stylissa sp., dan Polycarpa sp. Tiap sampel selanjutnya direndam dalam $100 \mathrm{~mL}$ pelarut etanol teknis dan ditempatkan dalam coolbox yang telah berisi es. Proses ini adalah untuk preservasi dalam proses transportasi ke laboratorium.

\section{Ekstraksi dan Pengujian Sitotoksisitas}

Kegiatan ekstraksi dan pengujian sitotoksisitas dilakukan di Laboratorium Pusat Penelitian dan Pengembangan Daya Saing Produk dan Bioteknologi Kelautan dan Perikanan (P3DSPBKP). Proses ekstraksi dilakukan sebanyak dua kali ulangan 
dengan menggunakan jenis pelarut dan volume yang sama dengan preservasi sampel. Total ekstrak tiap sampel yang diperoleh dari preparasi dan ekstraksi sebanyak dua kali ulangan adalah $300 \mathrm{~mL}$. Selanjutnya, ekstrak dari tiap sampel disaring dan dikeringkan berturut-turut dengan rotary evaporator dan freeze dryer. Penapisan awal sitotoksisitas dilakukan pada konsentrasi $100 \mathrm{ppm}$. Tiap uji dilakukan dengan tiga kali ulangan. Uji sitotoksisitas dilakukan dengan metode 3-(4,5-dimetiltiazol-2-il)-2,5-difeniltetrazolium bromid (MTT) berdasarkan Zachary (2003). Target pada uji sitotoksisitas adalah sel lestari tumor payudara MCF-7, kolon WIDr dan serviks HeLa. Konsentrasi penghambatan maksimal ekstrak sampel terhadap $50 \%$ populasi sel uji (inhibitory concentration 50 atau $I C_{50}$ ) dari tiap sampel ditentukan dari plot antara inhibisi pertumbuhan sel lestari target terhadap variasi seri konsentrasi (25, 50 dan $100 \mathrm{ppm})$ dari tiap sampel. Data $I C_{50}$ ini dipergunakan untuk analisis sistem konservasi di kawasan perairan Pulau Banda.

\section{Analisis Data}

Analisis data dilakukan secara desktriptif. Selain itu, informasi mengenai efektivitas konservasi yang telah dilakukan di perairan Pulau Banda diperoleh dari perbandingan data aktivitas sitotoksisitas hasil penelitian ini terhadap grafik korelasi antara kualitas lingkungan dan aktivitas sitotoksisitas referensi. Data sitotoksisitas sampel dari kawasan konservasi perairan Pulau Banda dibandingkan dengan data sitotoksisitas dari tiga karakteristik kualitas lingkungan hasil penelitian Januar et al. (2015b) menggunakan boxplot dan multidimensional scaling (MDS). Karakteristik kualitas lingkungan tersebut meliputi: sangat baik, yang dicirikan oleh nilai oksigen

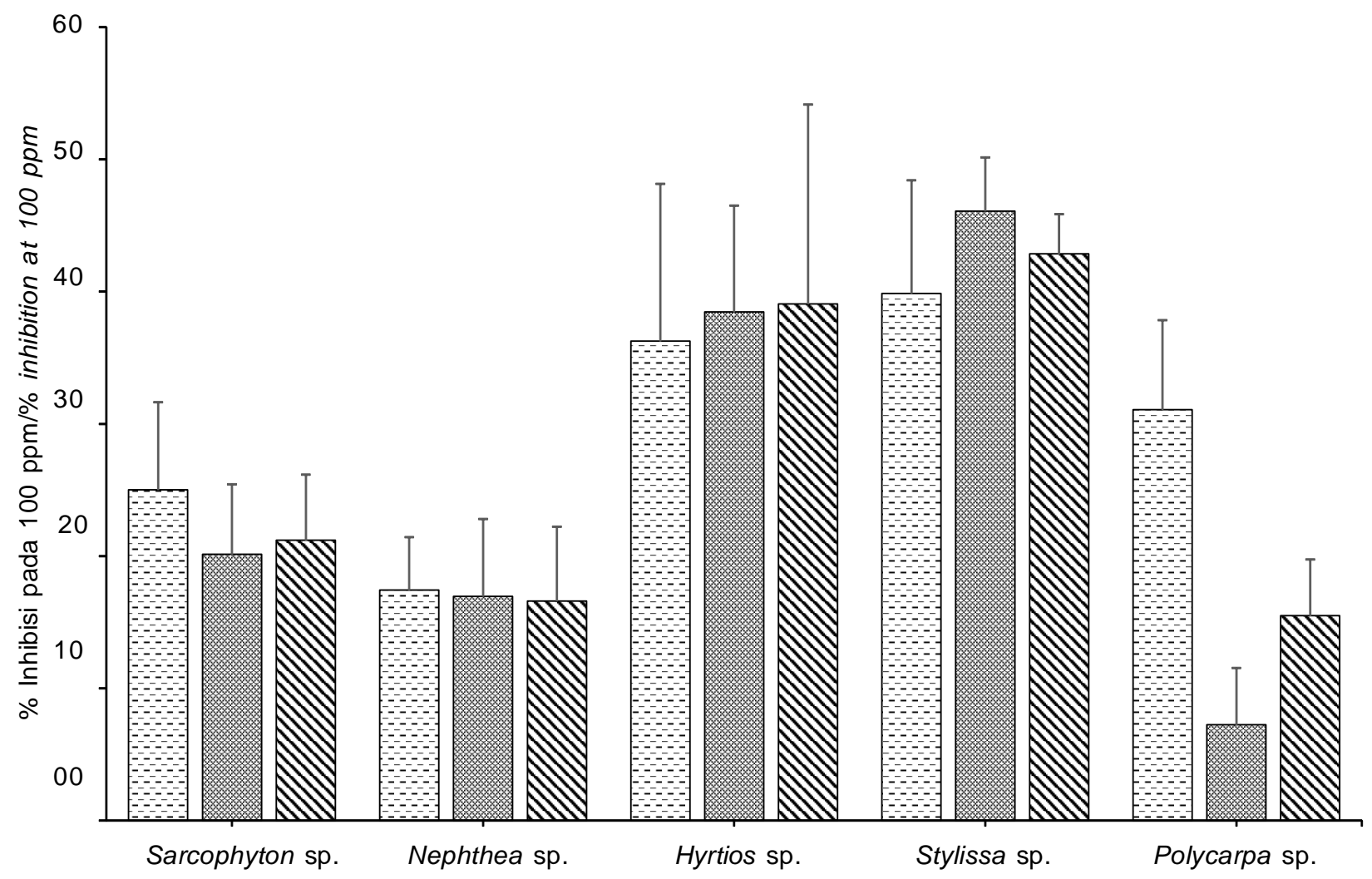

Genus sampel/Sample genus
$\boxminus$ MCF-7
ख WIDr
v HeLa

Gambar 1. Daya inhibisi ekstrak etanol Sarcophyton sp., Nephthea sp., Hyrtios sp., Stylissa sp. dan Polycarpa sp. asal perairan Pulau Banda terhadap sel lestari tumor MCF-7, WIDr, dan HeLa ( \pm SD)

Figure 1. Inhibitory Capacity of Sarcophyton sp., Nephthea sp., Hyrtios sp., Stylissa sp. and Polycarpa sp. ethanol extract from Banda Island water against MCF-7, WIDr, and HeLa cell lines $( \pm S D)$ 
terlarut (DO) dan pH tinggi; baik, yang dicirikan oleh tingkat cemaran fosfat dan nitrogen yang rendah; dan rendah, yang dicirikan oleh cemaran antropogenik yang tinggi karena dekat dengan pemukiman penduduk. Pengolahan data dilakukan dengan past statistical software (Hammer, Harper \& Ryan, 2001).

\section{HASIL DAN BAHASAN}

Penapisan menunjukkan bahwa golongan biota spons (Hyrtios sp. dan Stylissa sp.) memiliki sitotoksisitas yang lebih tinggi dibandingkan dengan karang lunak (Sarcophyton sp. dan Nephtheasp.) dan ascidian (Polycarpa sp.) (Gambar 1). Rataan

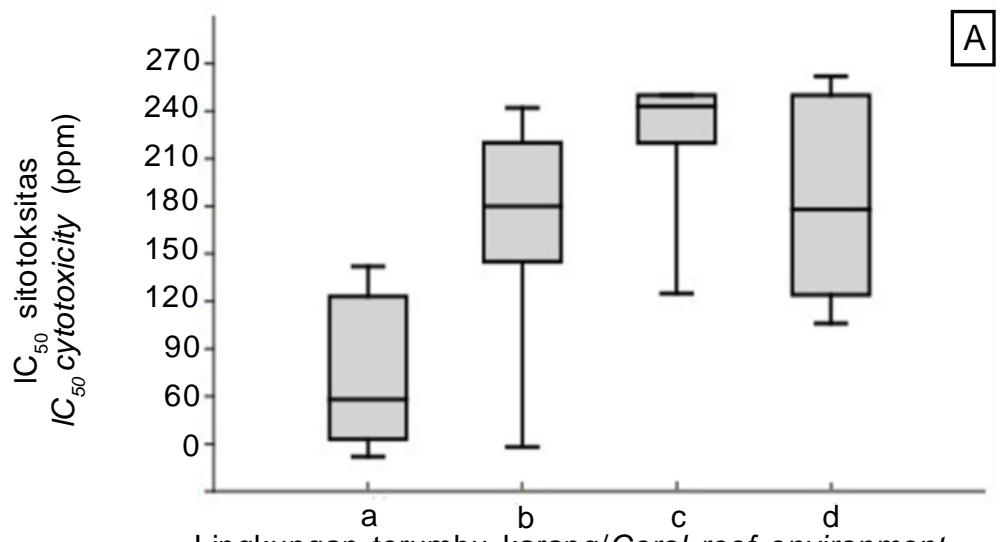

Lingkungan terumbu karang/Coral reef environment

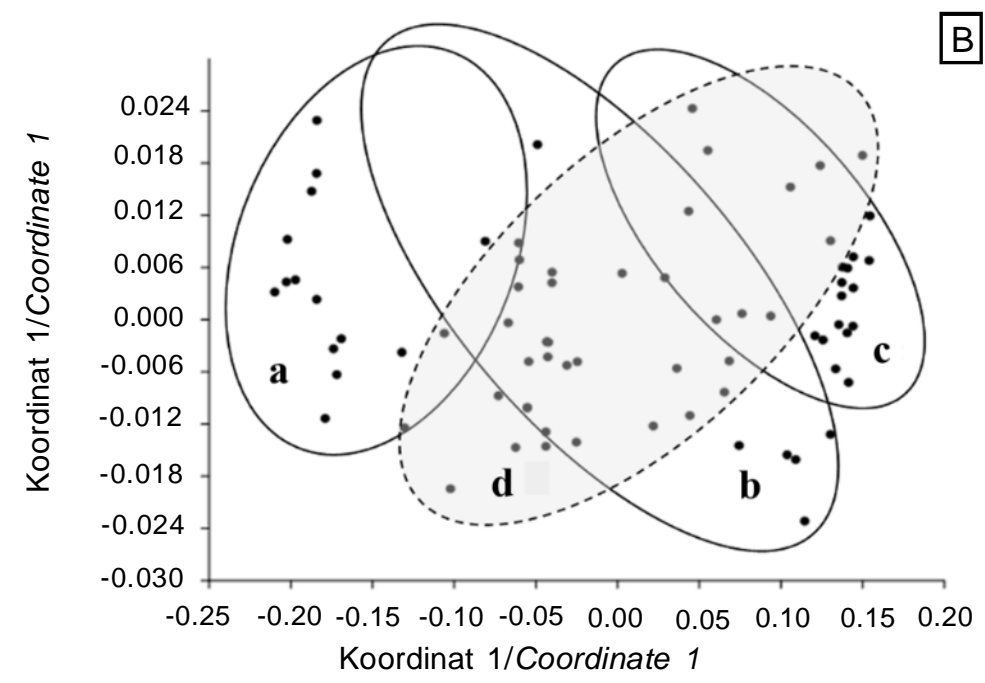

Keterangan/Note :

a : Perairan dengan kualitas sangat baik/waters with excellent quality

b : Perairan dengan kualitas baik/waters with good quality

c : Perairan dengan kualitas rendah/waters with low quality

d : Perairan Pulau Banda/Banda Island Waters

Gambar 2. Perbandingan boxplot (A) dan multidimensional scaling/MDS (B) dari IC ${ }_{50}$ sitotoksisitas ekstrak invertebrata laut (spons dan karang lunak) penelitian Januar et al. (2015b) dari perairan yang sangat baik (a), baik (b), dan rendah (c) terhadap ekstrak invertebrata laut dari kawasan konservasi perairan Pulau Banda (d)

Figure 2. Boxplot $(A)$ and multidimensional scaling/MDS $(B)$ comparison of $I C_{50}$ cytotoxicity from marine invertebrate (sponge and soft coral) extract in Januar et al. (2015b) study at excellent (a), good (b), and low (c) quality of environment to cytotoxicity found from marine protected area of Banda Island $(d)$ 
sitotoksitas dari tiap 100 ppm ekstrak biota spons adalah $40,43 \pm 9,17 \%$, sementara sampel karang lunak dan ascidian adalah sebesar $19,55 \pm 5,81 \%$ dan $17,94 \pm 11,32 \%$. Deviasi yang tinggi dari rataan sitotoksisitas ascidian Polycarpa sp. disebabkan adanya selektivitas sifat sitotoksik, dengan aktivitas yang lebih tinggi untuk sel lestari MCF-7 dibandingkan dengan WIDr dan HeLa. Sifat selektivitas ini hanya dimiliki oleh sampel asicidian. Sitotoksisitas sampel karang lunak dan spons tidak berbeda secara signifikan antar sel yang diujikan.

Berdasarkan penapisan sitotoksisitas yang dilakukan pada penelitian ini, maka biota spons Stylissa sp. memiliki potensi yang paling tinggi. Biota ini mengandung senyawa bioaktif yang mampu menghambat pertumbuhan sel lestari tumor paling tinggi. Penelaahan pustaka menemukan bahwa genus Stylissa memiliki ciri metabolit berupa senyawa alkaloid terbrominasi (Assmann, Van Soest \& Köck, 2001). Penelitian bioaktivitas spons Stylissa sp. dari wilayah perairan konservasi Karimunjawa (Jawa Tengah) sebelumnya telah menemukan senyawa halogenasi hymeniadisine, 3-bromo dimeniadiside, dan dibromophakelin (Januar, Wikanta, Fajarningsih \& Sugiyono, 2006; Januar, Motti, Tapiolas \& Wright, 2009). Selain itu, berbagai senyawa halogenasi nitrogen lainnya, misalnya bromopyrrole alkaloid, brominated pyrrole-2-aminoimidazole alkaloids, dan dispacamide juga telah dilaporkan dari jenis biota ini (Assmann et al., 2001; Ebada et al., 2015; Yarnold et al., 2012). Kelompok alkaloid terbrominasi telah diketahui memiliki sifat farmakologis untuk sitotoksisitas terhadap sel tumor, antibakteri, dan antifungi (Dembitsky, 2002). Oleh karena itu, biota Stylissa sp. di perairan Pulau Banda merupakan sumber plasma nutfah yang potensial sebagai sumber senyawa-senyawa baru bioaktif sehingga harus dijaga.

Secara umum, rataan bioaktivitas keseluruhan sampel tergolong rendah. Penelitian di wilayah perairan lainnya mendapatkan lebih banyak sampel yang memiliki sitotoksisitas yang tinggi. Penelitian Fajarningsih, Nursid, Januar dan Wikanta (2013) menunjukkan sampel dari perairan Kepulauan Wakatobi (Sulawesi Tenggara) mampu menghambat $50 \%$ pertumbuhan sel lestari tumor HeLa, MCF7, dan SKOV3 yang diujikan. Bahkan di lokasi yang serupa, penelitian terhadap Sarcophyton sp. dari perairan kaki gunung api Pulau Banda (di luar kawasan konservasi perairan Pulau Banda) memperoleh data inhibisi sel lestari tumor sebesar $60-70 \%$ pada konsentrasi ekstrak kasar yang serupa (Januar et al., 2016b). Hal ini memberikan hipotesis bahwa kualitas lingkungan di perairan dalam kawasan konservasi perairan Pulau
Banda tidak sebaik di tempat lainnya yang memiliki biota-biota dengan sitotoksisitas tinggi. Pembuktian dari hipotesis ini dilakukan dengan membandingkan data rataan $\mathrm{IC}_{50}$ dari keseluruhan sampel terhadap pola korelasi mutivariat antara kualitas perairan dan nilai sitotoksisitas spons dan karang lunak dari penelitian Januar et al. (2015b).

Pengolahan data secara statistik memperlihatkan bahwa sitotoksisitas biota invertebrata di kawasan konservasi perairan Pulau Banda terletak di antara perairan dengan kualitas lingkungan baik dan rendah (Gambar 2a). Analisis lanjutan dengan boxplot menunjukkan bahwa rentang nilai sitotoksisitas sampel dari perairan Pulau Banda tidak berbeda secara signifikan dengan sampel yang diperoleh di perairan dengan lingkungan baik dan rendah $(p>0,05)$. Namun nilainya berbeda secara signifikan terhadap bioaktivitas sampel yang diperoleh dari lingkungan sangat baik $(p<0,05)$. Telaah multivariat lebih lanjut memperlihatkan bahwa area koordinat sampel-sampel di perairan Pulau Banda bertumpang tindih dengan sampel-sampel dari perairan yang berkategori baik dan buruk (Gambar 2b).

Hasil perbandingan ini memperlihatkan bahwa kualitas lingkungan di kawasan konservasi perairan Pulau Banda menunjukkan karakteristik perairan baik dan rendah. Diduga wilayah perairan ini mengalami tekanan antropogenik eutrofikasi. Letak geografis perairan yang dekat dengan Desa Solomon dapat menjadi penyebab dari hal ini. Limpasan antropogenik dari wilayah daratan telah diketahui menjadi ancaman terhadap diversitas dan biopotensi yang dikandung oleh invetebrata laut (Aeby et al., 2011; Januar et al., 2015a). Aktivitas masyarakat lainnya, seperti penambangan karang ataupun pengambilan sumberdaya perikanan yang tidak ramah lingkungan, juga menjadi faktor antropogenik yang mengancam keberlangsungan terumbu karang (Caras \& Pasternak, 2009). Oleh karena itu, sistem konservasi di kawasan perairan Pulau Banda harus lebih dioptimalkan, untuk menjaga keberlangsungan plasma nutfah penghasil senyawa bioaktif yang terdapat di perairan ini.

\section{KESIMPULAN}

Kawasan konservasi perairan Pulau Banda memiliki biota Stylissasp. yang potensial mengandung senyawa bioaktif sitotoksik. Penelaahan lebih lanjut terhadap kondisi lingkungan menunjukkan dugaan bahwa perairan ini mengalami tekanan antropogenik berupa limpasan domestik dari pemukiman penduduk. Optimasi konservasi perairan harus lebih ditingkatkan, 
untuk menjaga sistem produksi metabolit bioaktif dari biota invertebrata di perairan ini.

\section{UCAPAN TERIMA KASIH}

Ucapan terima kasih penulis sampaikan kepada kolega di Taman Wisata Perairan Laut Banda, atas kerjasamanya selama melaksanakan penelitian lapangan.

\section{DAFTAR PUSTAKA}

Aeby, G.S., Williams, G.J., Franklin, E.C., Haapkyla, J., Harvell, C.D., Neale, S., Page, C.A., Raymundo, L., Vargas-Ángel, B., Willis, B.L., Work, T.M., \& Davy, S.K. (2011). Growth anomalies on the coral genera Acropora and Porites are strongly associated with host density and human population size across the Indo-Pacific. PloSOne, 6(2), e16887.

Assmann, M., van Soest, R. W., \& Köck, M. (2001). New Antifeedant Bromopyrrole Alkaloid from the Caribbean Sponge Stylissa caribica. Journal of Natural Products, 64(10), 1345-1347.

Bhakuni, D. S., \& Rawat, D. S. (2005). Bioactive metabolites of marine algae, fungi and bacteria. Bioactive Marine Natural Products, 1-25.

Caras T., \& Pasternak, Z. (2009). Long-term environmental impact of coral mining at the Wakatobi marine park, Indonesia. Ocean \& Coastal Management, 52(10), 539-544.

DeCaralt, S., Bry, D., Bontemps, N., Turon, X., Uriz, M.-J., \& Banaigs, B. (2013). Sources of secondary metabolite variation in Dysidea avara (Porifera: Demospongiae): the importance of having good neighbors. Marine Drugs, 11(2), 489-503.

Dembitsky, V. M. (2002). Bromo-and iodo-containing alkaloids from marine microorganisms and sponges. Russian Journal of Bioorganic Chemistry, 28(3), 170-182.

Ebada, S.S., Lin, W., \& Proksch, P. (2010). Bioactive sesterterpenes and triterpenes from marine sponges: occurrence and pharmacological significance. Marine Drugs, 8(2), 313-346.

Ebada, S.S., Linh, M.H., Longeon, A., de Voogd, N.J., Durieu, E., Meijer, L., Kondracki, M.L.B., Singab, A.N.B., Müller, W.E.G., \& Proksch, P. (2015). Dispacamide E and other bioactive bromopyrrole alkaloids from two Indonesian marine sponges of the genus Stylissa. Natural Product Resources, 29(3), 231-238.

Fajarningsih, N. D., Nursid, M., Januar, H. I., \& Wikanta, T. (2013). Bioprospeksi Spons, Karang Lunak dan Ascidian Asal Taman Nasional Laut Kepulauan Wakatobi: Antitumor dan Antioksidan. Jurnal Pascapanen \& Bioteknologi Kelautan dan Perikanan, 8(2), 161-170.

Fabricius, K. (2008). A brief photo guide to the shallow water octocorals of the Rowley Shoals, Western Australia. Australian Institute of Marine Science. 39pp.
Faulkner, D.J. (2001). Marine natural products. Natural Product Reports, 18, 1-49.

Haber, M., Carbone, M., Mollo, E., Gavagnin, M., \& Ilan, M. (2011). Chemical defense against predators and bacterial fouling in the Mediterranean sponges Axinella polypoides and A. verrucosa. Marine Ecology Progress Series, 422, 113-122.

Hammer O., Harper D.A.T., \& Ryan P.D. (2001). Past : Palaeontological Statistics Software package for education and data analysis. Palaeontological Electronic, 4(1), 9pp.

Harvey, A.L. (2008). Natural products in drug discovery. Drug Discovery Today, 13(19), 894-901.

Hoeksema, B.W., \& De Voogd, N.J. (2012). On the run: free-living mushroom corals avoiding interaction with sponges. Coral Reefs, 31(2), 455-459.

Hooper, J.N.A. (2003). Sponge Guide: Guide for sponge collection and identification. Queensland Museum, Australia, 24pp.

Januar, H.I., Wikanta, T., Fajarningsih, N.D., \& Sugiyono. (2006). A case of study: Antibacterial agent from Axinella sp. and the environmental parameters of its habitat. Makalah seminar di Seminar dan workshop internasional dalam bidang biodiversitas laut, Jakarta, 17 Mei 2006.

Januar, H.I., Motti, C., Tapiolas, D., \& Wright, A.D. (2009). Analisis dereplikasi untuk identifikasi senyawaan antibakteri spons Axinella sp. dari Perairan Kepulauan Karimunjawa. Jurnal Pascapanen \& Bioteknologi Kelautan dan Perikanan, 4(1), 79-86.

Januar, H.I., Hendrarto, B., Chasanah, E., \& Wright, AD. (2011). Nephthea sp.: Correlation between natural products production and pressure from local environmental stressors. Journal of Marine Science Research \& Development, S8:001. DOI: 10.4172/ 2155-9910.

Januar, H.I., Marraskuranto, E., Patantis, G., \& Chasanah, E. (2012). LC-MS Metabolomic Analysis of Environmental Stressors Impacts to the Metabolites Diversity in Nephthea sp. Chronicle of Young Scientist, 2(4), 57-62.

Januar, H.I., Pratitis, A., \& Bramandito, A. (2015a). Will the increasing of anthropogenic pressures reduce the biopotential value of sponges? Scientifica. ArticleID: 734385.

Januar, H.I., Chasanah, E., Tapiolas, D.M., Motti, C.A., Liptrot, H.L., \& Wright, A.D. (2015b). Influence of anthropogenic pressures on the bioactivity potential of sponges and soft corals in the coral reef environment. Squalen Bulletin of Marine \& Fisheries Postharvest \& Biotechnology, 10, 51-59.

Januar, H.I. (2016a). North-South BioDiscovery Research Collaboration of Indonesian Sponge and Soft Coral : A Bibliographic Analysis of Publications Over the Last Two Decades. Journal of Scientometric Research, 5(1), 43-48.

Januar, H.I., Zamani N.P., Soedharma, D., \& Chasanah, E. (2016b). Changes in soft coral Sarcophyton sp. 
Abundance and cytotoxicity at volcanic $\mathrm{CO} 2$ seeps in Indonesia. AIMS Environmental Science, 3(2), 239248.

Kelly, S.R., Jensen, P.R., Henkel, T.P., Fenical, W., \& Pawlik, J.R. (2003). Effects of Caribbean sponge extracts on bacterial attachment. Aquatic Microbial Ecology, 31(2), 175-182.

Kiuru, P., D’Auria, M.V., Muller, C.D., Tammela, P., Vuorela, H., \& Yli-Kauhaluoma, J. (2014). Exploring marine resources for bioactive compounds. Planta Medica, 80(14), 1234-1246.

Leal, M.C., Puga, J., Serôdio, J., Gomes, N.C.M., \& Calado, R. (2012). Trends in the discovery of new marine natural products from invertebrates over the last two decades-where and what are we bioprospecting? PloSOne, 7(1), p.e30580.

Pawlik, J.R. (2011). The chemical ecology of sponges on Caribbean reefs: natural products shape natural systems. BioScience, 61(11), 888-898.

Yarnold, J. E., Hamilton, B. R., Welsh, D. T., Pool, G. F., Venter, D. J., \& Carroll, A. R. (2012). High resolution spatial mapping of brominated pyrrole-2aminoimidazole alkaloids distributions in the marine sponge Stylissa flabellata via MALDI-mass spectrometry imaging. Molecular BioSystems, 8(9), 2249-2259.

Zachary, I. (2003). Determination of cell number, in: Cell proliferation and apoptosis. Hughes, D. \& Mehmet, H. (eds), Bios Scientific Publishers, 1335. 